If you no longer need this publication write to the Geological Survey in Washington for an official mailing label to use in returning it

UNITED STATES DEPARTMENT OF THE INTERIOR

\title{
TOPAZ DEPOSITS NEAR THE BREWER MINE, CHESTERFIELD COUNTY, SOUTH CAROLINA
}

GEOLOGICAL SURVEY BULLETIN 936-C

\section{WHLLIAM O. JENKINS}

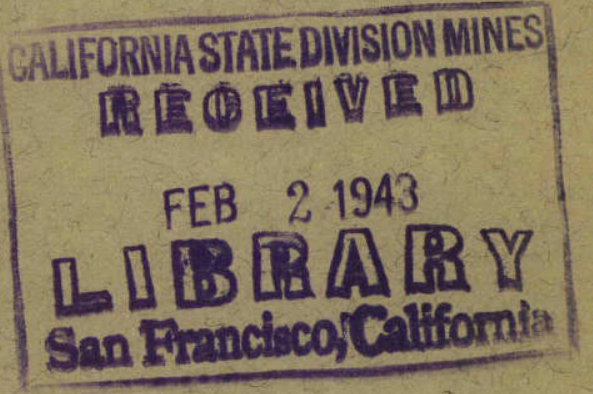



UNITED STATES DEPARTMENT OF THE INTERIOR

Harold L. Ickes, Secretary

GEOLOGICAL SURVEY

W. C. Mendenhall, Director

Bulletin 936-C

\section{TOPAZ DEPOSITS NEAR THE BREWER}

\section{MINE, CHESTERFIELD COUNTY \\ SOUTH CAROLINA}

BY

CARL FRIES, JR.

Strategic Minerals Investigations, 1942

(Pages 59-78)

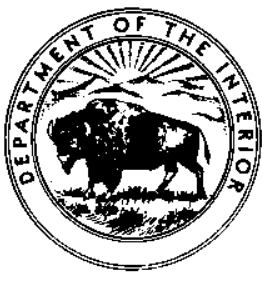

UNITED STATES

GOVERNMENT PRINTING OFFICE

WASHINGTON : 1942

For ale by the Superintendent of Documente, Washington, D. C. - . . - - - - Price 30 cents 

Abstract................................ 59

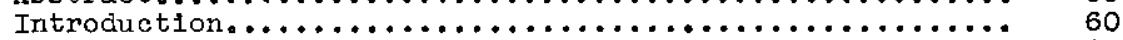

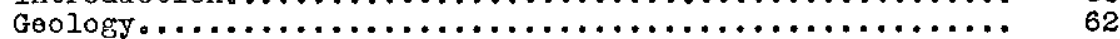

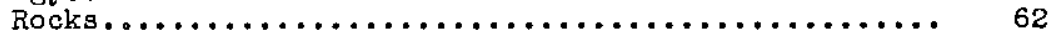

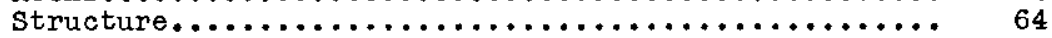

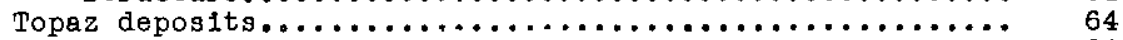

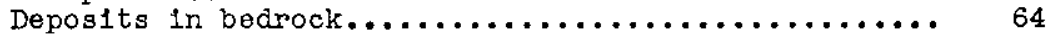

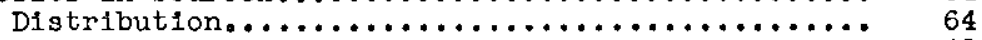

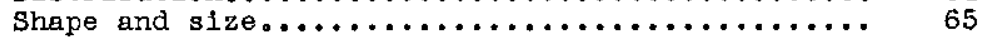

Character and composition of the topaz rock..... 67

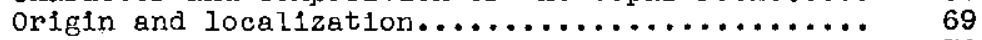

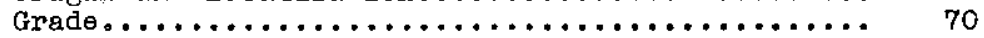

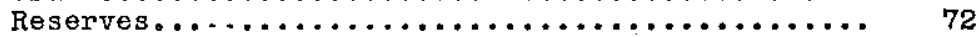

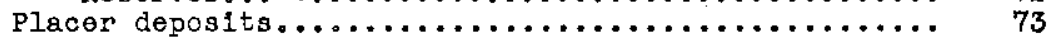

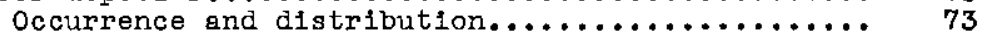

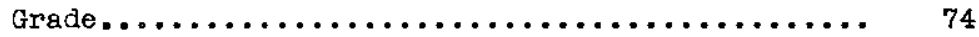

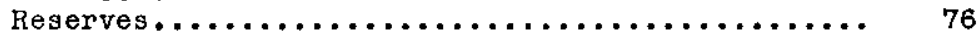

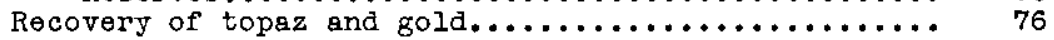

\section{ILLUSTRATIONS}

Page

Plate 6. Geologic map of Brewer mine and viclnity,

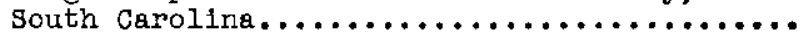

7. Map of topaz deposits near Brewer mino, South

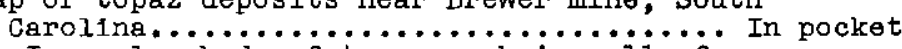

8. A, Irregular body of topez rock in wall of open p1t; B, Banded topaz rock cut by velnlots of "buil" quartz; $\underline{\mathrm{C}}$, Brecciated sillcifled rock partly replaced by topaz.......... 66

9. Map of new excavation for topaz rock near the Brewer mine, August $1941 \ldots \ldots \ldots \ldots \ldots \ldots \ldots \ldots . \ldots \ldots$

Flgure 3. Map of South Carolina showing location of topaz

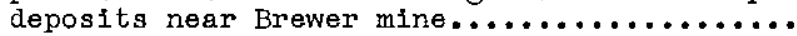

\section{TABLES}

Table 13. Chemical analyses of topaz rock............ 69

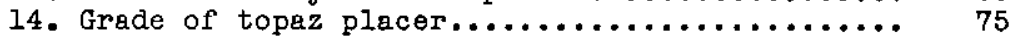

15. Reserves of topaz in placer ground........... 77 

TOPAZ DEPOSITS NEAR THE BREWER MINE,

CHESTERFIELD COUNTY, SOUTH CAROLINA

By Carl Fries, Jr.

ABSTRACT

Lode and placer deposits of massive topaz rock were discovered near the old Brewer gold mine in northwestern Chesterfield County, S. C., in 1935. Preliminary tests have shown that this rock can be used in the manufacture of refractory ware and as a source of mullite, thus augmenting supplies of kyanite that have been coming from India. About 700 tons of topaz rock had been mined up to August 1941, largely for experimental uses.

The country rock in the region is a quartz-sericite schist derived from fine-grained rhyolitic tuff and breccia. In places the schist is completely silicified and contains pyrite and gold. A part of the topaz is in some of this sillcifled rock that extends northwest from the old Brewer open pit. Remnants of marine Cretaceous sands and gravels form a thin veneer on the schlsts just south of the topaz area. The schlst and silicified rock have been deeply weathered, in places to a depth of at least 170 feet. The topaz is extremely resistant to weathering and has remained hard and unaltered in the surrounding friable decomposed rocks.

The topaz forms irregular replacement bodies, ranging in thickness from a fraction of an inch to about 10 feet, which appear to be grouped roughly along lines that trend northeast and northwest, the longest group observed being about 100 feet long. The topaz also forms narrow veinlets that cut across the follation in the schist, and thin lenses in the planes of schistosity; and grains of topaz are disseminated in the schist at some places. The sllicification, sulfidization, and deposition of gold may be related to a large body of blotite granite which has intruded the schist and which is exposed a mile and a half northwest of the topaz-bearing area. The origin of the topaz is less clear.

The topaz near the Brewer mine contains from 13 to 14 percent fluorine. Tests made in the Geological Survey laboratorles indicate that when the topaz is calcined at $1.350^{\circ} \mathrm{C}$. the fluorine is expelled with part of the silicon as silicon tetrafluorlde, leaving a residue composed of alumina and silica in the ratio $3: 2.24$, which is close to the $3: 2$ ratio of mullite. It is possible that some compound of fluorine could be recovered as a byproduct.

The district contains probable reserves amounting to about 106,000 tons of rock averaging at least 15 percent topaz; this materlal contains roughly 16,000 tons of topaz, most of which probably can be recovered. In addition, there are possible 
reserves of about 194,800 tons of topaz-bearing rock of the same grade, which would contain roughly 29,000 tons of topaz. Fur- . ther exploration may reveal other zones of sufficient size to mine. Assays indicate that the silicified rock in which the topaz occurs contains about 0.05 ounce of gold a ton, of which possibly 40 percent might be recovered with the topaz.

Deposits in the area composed mainly of residual soll containing fragments of topaz can be worled as placers, and some of these have been tested. The placers contain about 62,500 cubic yards of material averaging 280 pounds to the cubic yard, which would amount to about 8,750 tons in all, of coarse topaz (that in pleces more than a quarter of an inch in diameter). They also contain about 3,270 tons of fine topaz, but it is not certain how much of this could be recovered. Most of the placers contain about 50 cents worth of gold a cubic jard, of which possibly haif might be recovered with the topaz.

\section{INTRODUCTION}

Bedrock and placer deposits of massive topaz rock occur near the old Brewer gold mine, which is a mile and a half northwest

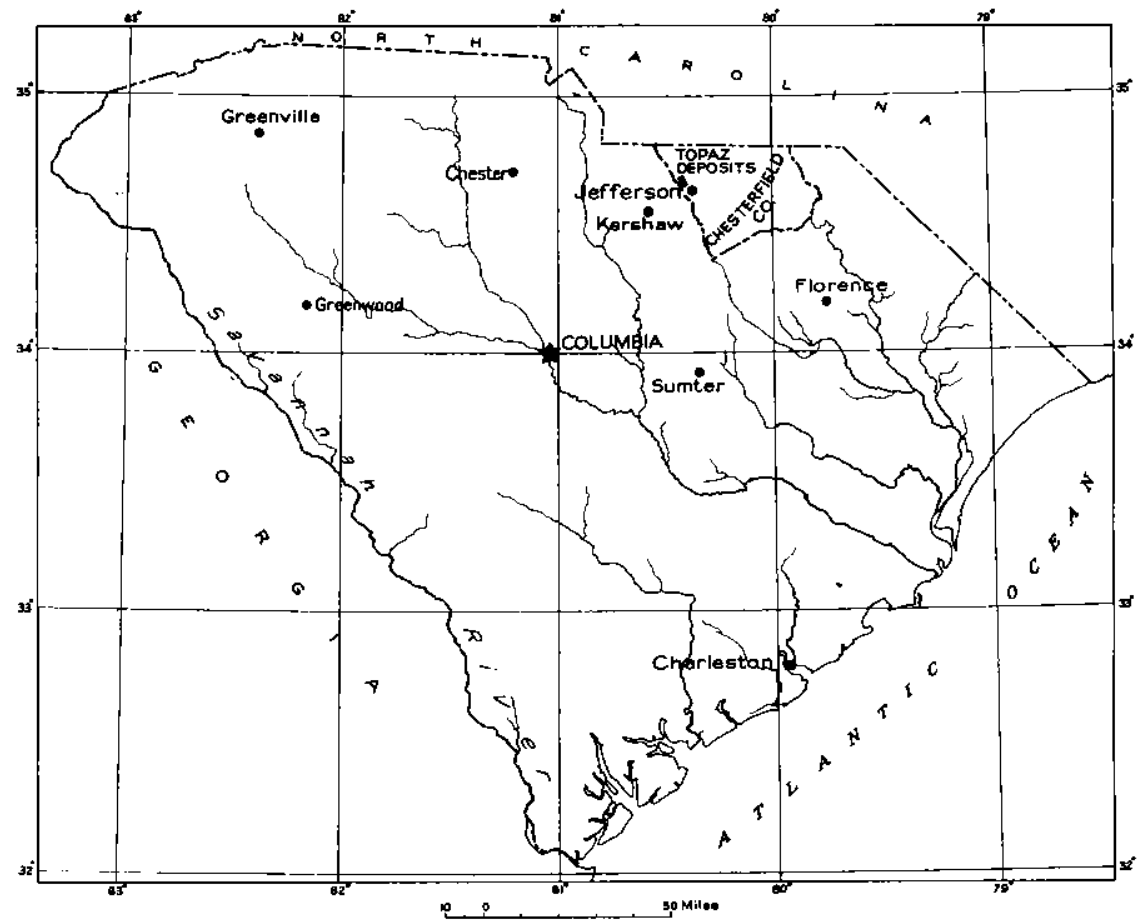

Figure 3.--Nap of South, Carolina showing location of topaz deposits near Brewer mine.

of the town of Jefferson, Chesterfield County, S. C. (flg. 3). The deposits may be reached by way of a dirt road, a mile and a 
half long, that extends northward from State Highway 265 a mile west of Jefferson. This highway reaches the nearest rallroad, a branch of the Norfolk \& Western, at Kershaw, 13 miles southwest of Jefferson.

Although gold has been mined intermittently from the Brewer area for about a hundred years, the massive topaz was not recognized unt1l 1935, when a study was being made of the gold deposIts of the southern Appalachian region by J. T. Pardee and C. F. Park, Jr. for the Geologlcal Survey, Unlted States Department of the Interior. The topaz was described by Pardee, Glass, and Stevens $1 /$ and by Glass $2 /$ in 1937. The United Feldspar \& Minerals Corporation, which has acquired control of the topaz-bearing area, conducted preliminary tests during 1939 and 1940 on the grade of the deposits and on prospective uses for the topaz; some of the results of these tests have been described by Burgess. 3/ In 1941 the company began mining topaz from bedrock, largely for exploratory and experimental purposes, while continuing teris on possible uses for the material, and by August of that year about 200 tons of topaz mined from bedrock and 500 tons of topaz float had been shlpped to prospective consumers. The topaz will be used mainly to augment and replace supplies of kyanite in the manufacture of refractory ware; much of the kyanite and some topaz has been coming from India. Fluorine might possibly be recovered as a byproduct in processing.

The author, assisted by J. J. Page, gave three weeks in August 1941 to mapping the topaz-bearing area and testing poss1ble placer ground. Samples of placer material were further

\footnotetext{
1/ Pardee, J. T., Glnse, Jerell J., and Stèrens, R. E., Massive lowfluorine topaz from the Brewer mine, South Carolina: Am. Minerelogist, vol. 22, pp. 1058-1064, 1937.

2) Glass, Jewell J., Bristraorinary topaz-replacement body in the Brever mine, South Carolina: Am. Geophys. Union Trans., 18th Ann. Meeting, pp. 243$246,1937$.

3/ Burge日s, B. C., Topaz, a new Industrial mineral: Mng, and Min. Jour., vo1. 142, pp. 57-58, Sept. 1941.
} 
Investigated by the author and J. J. Glass in the laboratories of the Geological Survey, and samples of bedrock collected in 1939 by C. S. Ross and J. J. Glass, of the Geological Survey, were also studied.

The author is grateful to Mr. B. C. Burgess, of the United Feldspar \& Minerals Corporation, and his employees for their complete cooperation and aid in field work. For help in the office he is indebted to many members of the Geological survey, particularly to $K$. J. Murata for advice relating to interpretation of chemical analyses, to J. J. Glass and C. S. Ross for discussions concerning the origin of the deposits, and to H. G. Ferguson and F. C. Calkins for constructive criticlsm of the manuscript.

\section{GEOLOGY}

\section{$\underline{\text { Rocks }}$}

The rock in the vicinity of the topaz deposits is mainly schist (see pl. 6) composed largely of quartz and sericite. In places the schist contains layers rich in pyrophyllite; its minor constituents include chloritold, epidote, zolsite, biotite, kyanite, feldspar, topaz, limenite, rutile, zircon, and oxides of iron. Parts of the schist retain a banded structure representing original bedding, and other parts retain the pattern of a fine-grained breccia. Pardee and Park $4 /$ believe that the schist represents metamorphosed fine-grained rhyolitic tuffs and brecclas. A large body of blotite granite which has intruded the schist is exposed about a mile and a half northwest of the topaz-bearing area.

The topez deposits are largely in a zone of silicified rock which extends northwestward for about 1,200 feet from the Brewer pit. (See pl. 6.) The silicified rock is light to dark gray, 
UNITED STATES DEPARTMENT OF THE INTERIOR GEOLOGICAL SURVEY

\section{EXPLANATION}

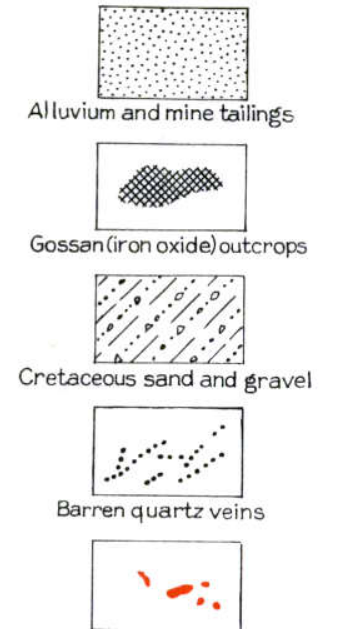

Outcrops of topaz rock
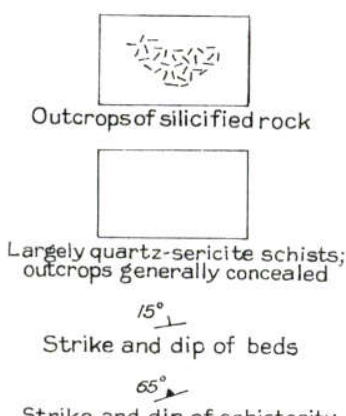

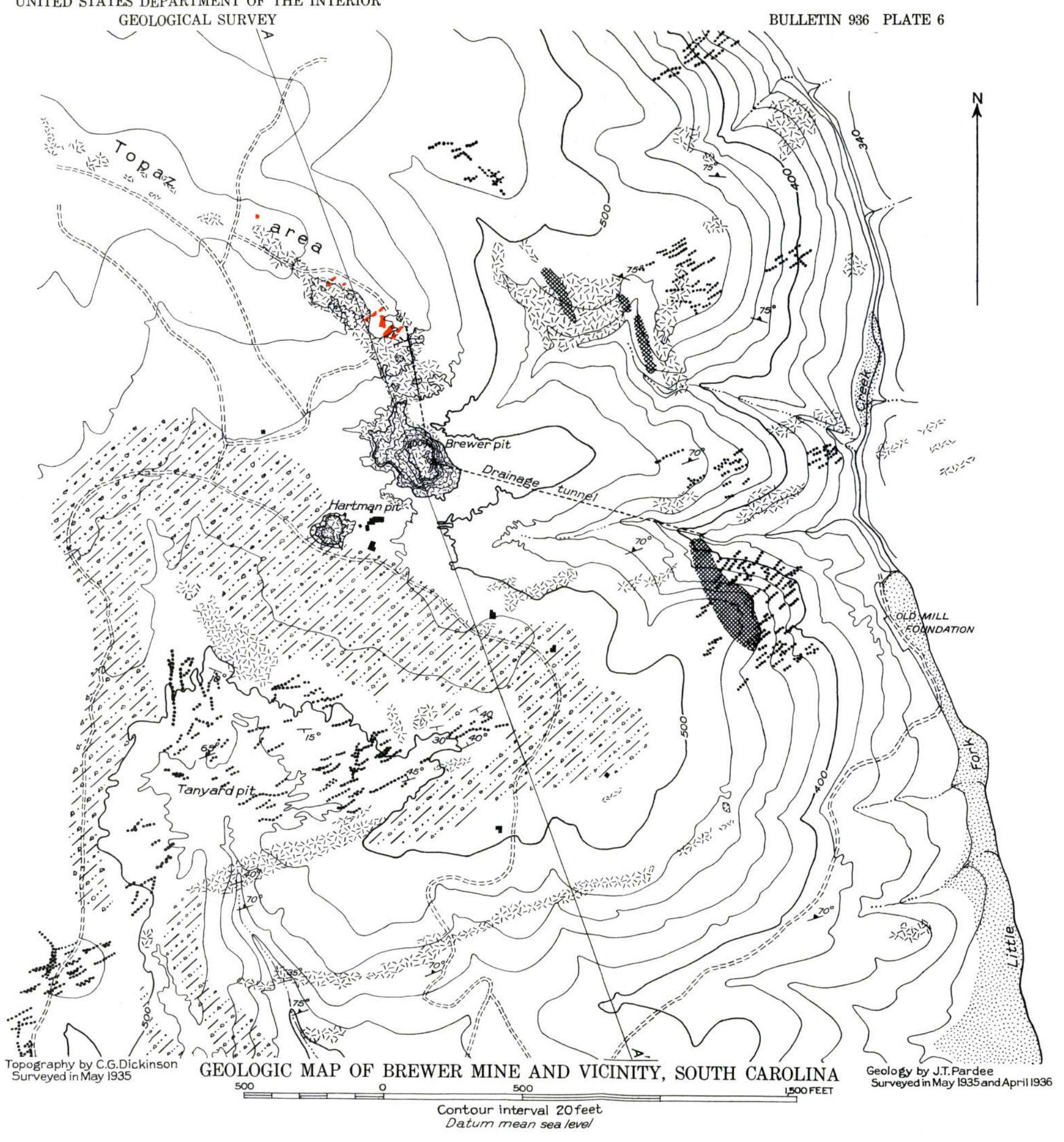

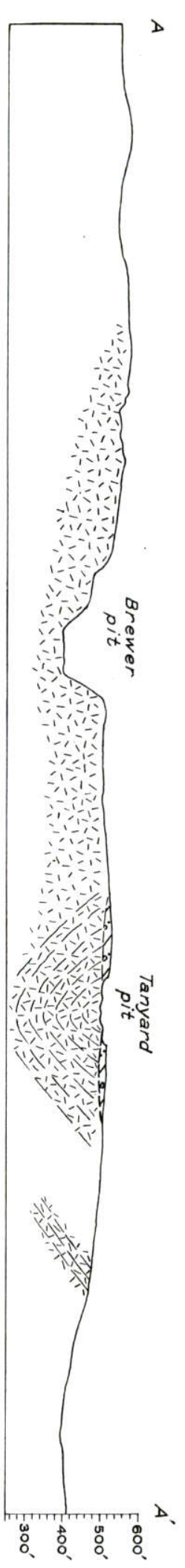



and is marked in part with the pattern of a breccia and in part with bands and laminae. It is composed mainly of fine-gralned quartz but contains also small quantities of sericite, kyanite, topaz, ilmenite, and sulfides, chiefly pyrite. Rare constituents are enargite, covellite, $\frac{5}{\text { cassiterite, }}, \frac{6}{\text { bismite }}, \frac{7}{\text { native }}$ bismuth, 7 and native gold.

Narrow northeast-trending veins of coarse-gralned white "bull" quartz cut the schist and the rock of the silicified zones in the vicinity of the Brewer pit. This quartz appears to be barren, except for small quantities of ilmenite.

Remnants of marine Cretaceous sand and gravel $9 / 5$ to 15 feet thick overlie the schlst south of the topaz-bearing area. (See pl. 6.) The sand and gravel appear to be of local origin, as they consist mainly of quartz sand together with pebbles of schist and silicifled rock. These remnants lie only 20 to 30 feet lower than the top of the ridge on which the topaz crops out, and it seems probable that similar beds once extended over the crest of the ridge and were removed by erosion in geologically very recent time. Some of the pleces of topaz float along this ridge are well worr, as if they had once been pebbles in the Cretaceous deposits.

Both the schlst and the silicified rock, together with their veinlets of "bull" quartz, have been deeply weathered, particularly where fissures are numerous, the process having extended in places at least as deep as the bottom of the Brewer open pit, 140 feet below the surface. This weathering appears largely to have preceded the deposition of the Cretaceous beds. The weathered rock is generally white and friable, breaking down

5/ Becker, G. F., Gold flelds of the southern Appalachlans: U. S. Geol. Survey I6th Ann. Rept., pt. 3, p. 279, 1895.

6) Iden, p. 308 .

I) Tuomey, Michael, Report on the geology of South Carolina, p. 97, 1848.

8/ Pardee, J. T., Glass, J. J., and Stevens, R. E., op. c1t., p. 1059.

9) Pardee, J. T., and Park, C. F., Jr., op. c1t. $4547600-42-2$ 
Into sand when struck with a hammer, but some is stalned yellow and brown with I Imonite and is somewhat more firm. Part of the silica has been leached out in weathering, thus allowing the silicified rock to disintegrate to sand; the sillcates have been altered to clays; and the iron-bearing minerals have been altered to hydrous iron oxides, thus freeing the gold in the pyrite. The topaz and kyanite were extremely resistant and are generally unaltered.

\section{Structure}

Follation in the schist just south of the Brewer pit (see pl.6) strikes about $N_{5} 70^{\circ} \mathrm{E}$. and dips $65^{\circ}-70^{\circ} \mathrm{N} .$, according to

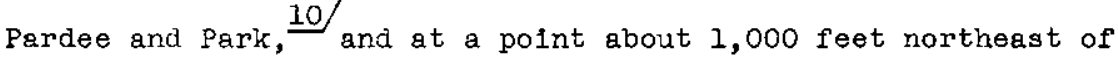
the pit 1 t strikes $\mathrm{N}$. $30^{\circ} \mathrm{N}$, and dips steeply north; it is obscure in the topaz area. Pardee and Park belleve that the topaz area is in the north limb of a westward-pitching syncline whose axis lies about 1,000 feet south of the Brewer open pit.

Several groups of fractures cut the silicified rock in the Brewer pit: One group strikes northwest and dips steeply northeast, a second group strikes northeast and dips $40^{\circ} \mathrm{SE}$., and a third strikes northeast and dips northwest. Movement has taken place along one or more of the fractures in each group. A fault with 3 feet of breccla that crosses the drift north from the bottom of the Brewer pit (see pl. 7) strikes nearly west and dips $65^{\circ} \mathrm{N}$.

TOPAZ DEPOSITS

\section{Deposits in bedrock}

Distribution.--Massive topaz rock crops out or is exposed in prospect shafts at more than a dozen places along the crest of the northwest-trending ridge that begins at a point a few hun-

10/ Pardee, J. T., and Park, C. F., Jr., op. c1t. 
dred feet north of the Brewer open pit. (See pl. 7.) The outcrops are most abundant between the placer areas designated 1 and $1 \mathrm{~A}$ on plate 7 and form an elongate zone parallel to the ridge. The topaz rock occurs in the walls of an old incline shaft and stope that extends to a depth of 45 feet under the outcrops in this area. It occurs also, 170 feet below the surface, in the walls of an old drift that extends 420 feot north from the bottom of the Brewer pit, largely within 150 feet from the face of the drift; the drift ends 50 feet east of a point vertically under the easternmost outcrop of the massive topaz. The dumps from two old shafts, caved and fllled with rubble, at the west edge of placer area 1 contain some blocks of topaz excavated from the bedrock there. There are two small outcrops of topaz rock in the north wall of a large old open pit just south of these shafts. Westward from this point for a distance of 300 feet there is no topaz float along the top of the ridge. Topaz is exposed in a shallow shaft at the east end of placer area 2. A group of large blocks of topaz float fust northwest of the center of this area indicates that the bedrock source is within a few feet of the surface there. The abundance of smaller pleces of topaz float along the ridge top in this area Indicates that topaz probabiy occurs at several other places in the underlying bedrock but not so close to the surface. The abundance of topaz float scattered over placer area 3 , which is surrounded by barren ground, indicates that the topaz probably occurs at several places in the bedrock underlying this area. The topaz-bearing bedrock must be close to the surface in the northwestern part of the area, for blocks as large as 3 feet in diameter, composed of unsilicifled schist containing topaz, are abundant on the surface there and cannot be far removed from bedrock.

Shape and size.--Although some of the topaz is in small grains disseminated through parts of the silicified schist, most 
of it occurs in replacement bodies that range from a fraction of an inch to about 10 feet in thickness. The forms assumed by these bodies include knots, clumps, lenses, veins, and irregular masses such as the one shown in plate B, A. Although in detail the replacement bodies seem to have no trend, in general they appear to be grouped at irregular intervals along branching planes in the sillcifled schist. Vlewed broadly, the bodies appear to form intersecting zones that strike northwest and northeast, as shown in plates 7 and 9 , and to have nearly vertical dips. Exploretory work has not yet been extensive, but from its exposures and outcrops the most prominent zone of the topaz rock appears to be continuous for at least 100 feet.

The large blocks of schist on the surface in the westermmost area of placer contain hard ribs of topaz, ranging from oneoighth to haif an inch in thicknoss and from 1 to 6 inches in length, most of which extend along the planes of follation. Some of these blocks also contain scattered, irregular topaz velnlets half an inch thick that cut across the follation. The size and shape of the masses of rock of this type are not known, owing to lack of outcrops and exploration. Neither is the extent known to which topaz is disseminated in the schist.

The contact of the topaz rock with the silicified schist is generally not distinct; the two are commonly separated by a transitional zone which varies in thickness from a fraction of an inch to severel feet. The topaz rock retains either a faint banding ( $s e \theta$ pl. 8, B) or the pattern of a breccla (see pl. 8, $\underline{\text { ), }}$ which are textures that hove been carried over from the silicified schist. Around the borders of the rock that is completely replaced by topaz there remain fragments or seams of silicified rock that contains no topaz. The polished surface of a specimen of such rock, which was photographed with spocular 1llumination, is shown in plate 8, $\underline{\mathrm{C}}$; here a dark matrix composed mainly of topaz (T) Incloses many light-colored fragments of silicified 

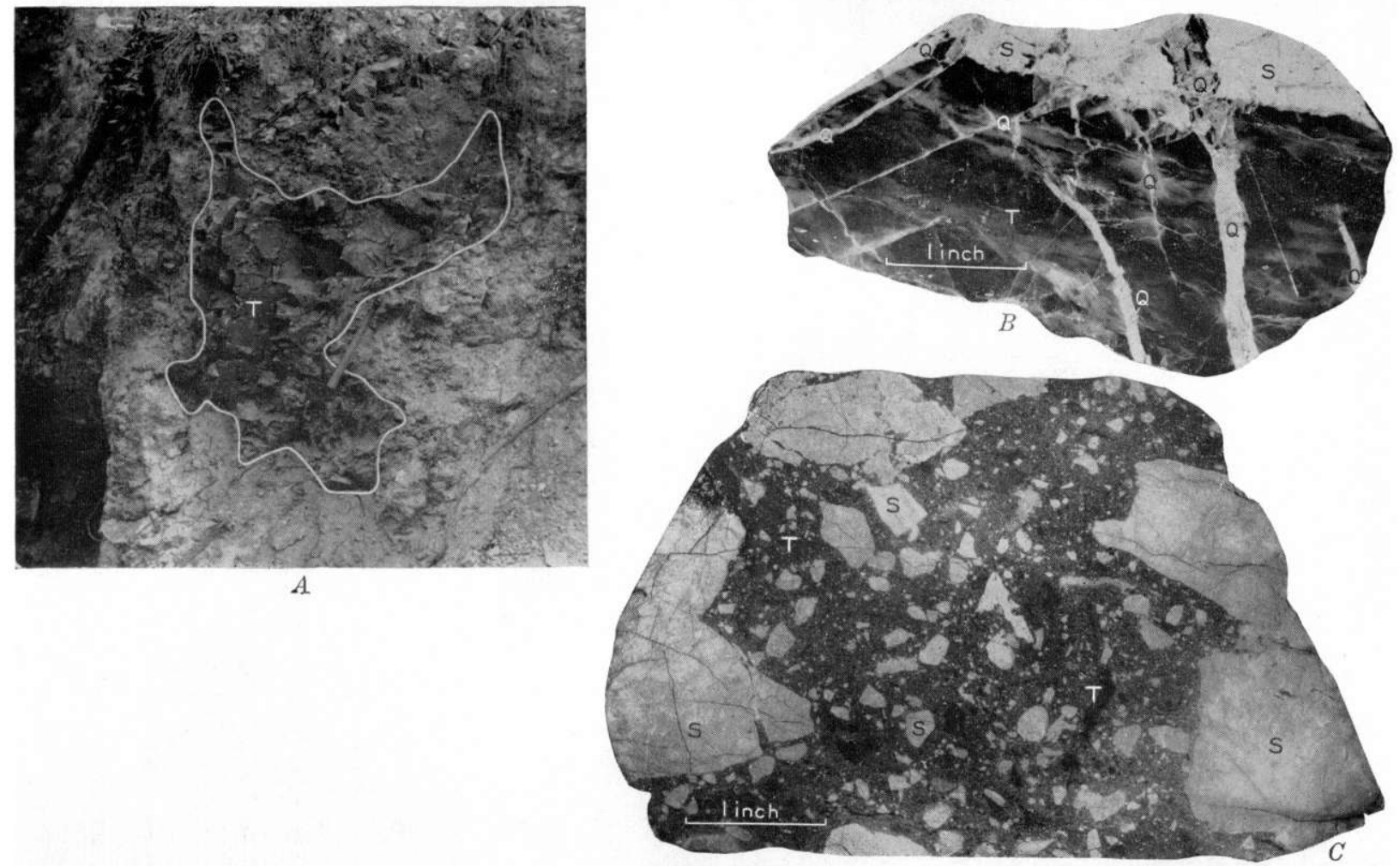

$A$. Irregular body of topaz rock in wall of open pit. Show fracture pattern in body of hard, compact topaz rock, $T$; body is surrounded along indefinite $B$. Polished specimen of banded topaz rock cut by veinlets of "bull" quartz. Banded topaz, $T$ (dark), has replaced part of the silicified schiet, $S$, and both are cut by veinlets of "bull" quartz, $Q$.
C. Polished specimen of brecciated silicified rock partly replaced by topaz. Topaz, $T$ (dark), has replacel parts of the matrix and some of the fragmente of
the brecciated silicified ochiet, $S$. 

rock (S) that have not been replaced by topaz and a few dark fragments that consist wholly of topaz. Such a mixture of quartz and topaz is typical of a part of the deposit. Rock of this type where strongly weathered forms a knotty, porous mess, because the sllicified fregments are leached while the more resistant topaz remains dense and hard. A decrease in topaz content around the bodies of massive topaz in the weathered zone 1s accordingly expressed by a decrease in compactness of the rock. In a few places seams and narrow veinlets of white "bull' quartz cut through the topaz rock, as shown in plate 8 , A.

Character and composition of the topaz rock. - The topaz rock forms dense massive fine-grained bodies in the eastern part of the district and dense massive medium-grained bodies in the western part of the district. The flne-grained topaz rock varles from colorless to dark gray and $1 \mathrm{~s}$ streaked and mottled. The topaz gralns are so ting that even under the highest power of the microscope they appear merely as points of light. This rock breaks with concholdal fracture and has the appearance of chert. Its hardness is about 7, and it is extremely tough, as shown by a compression test made in the laboratories of the Pub. 11c Roads Administration of the Federal Works Agency. A block 1 Inch high with a section area of 0.694 square inch required a load of 67,700 pounds, or a unit load of 97,600 pounds. Minute inclusions of pyrite are present in some of the rock, and some pleces of float are reddish brown on the inside, owing probably to oxidation of this pyrite.

The medium-grained topaz rock has the texture and appearanc of marble on freshly broken surfaces. The color of the float 1 light brown, owing to films of limonite along the grain boundaries, but the unweathered rock is probably white. The rock con tains a few inclusions of ilmenite. It is as hard as the finegrained type, but no test has been made of its compressive strength, which is probably not as great. 
The chemical formula of topaz as given by Dang $11 / 1 \mathrm{~s}$ $\mathrm{Al}(\mathrm{F}, \mathrm{OH}) 2^{\mathrm{AlSiO}_{4}}$, which indicates that $\mathrm{F}^{-}$and $\mathrm{OH}^{-}$may replace each other to some extent. Chemical analyses show that the Brewer topaz has between 13 and 14 percent fluorine (see table 13, columns 1 and 2), which is the lowest recorded in any topaz. An assay of the massive fine-grained topaz rock from the area north of the Brewer pit gave 0.01 ounce of gold per ton. $12 /$ Spectrographs of this topaz made in the Survey laboratories by George steiger showed traces of tin, germanium, and silver.13/ Chemlcal analyses of flve types of topaz rock from the Brewer area are given in table 13, which also includes analyses of two of the samples after heating for half an hour at $1350^{\circ} \mathrm{C}$. , the approximate temperature of calcination.

The samples that were calcined were crushed to a fine powder and heated for half an hour at $1350^{\circ} \mathrm{C}$. The light red-brown powders turned snow white on heating, and they were then found, under the microscope, to contain numerous minute needles of mullite. The analyses of the heated samples (2a and $5 a$ in table 13) show these have lost all their $\mathrm{H}_{2} \mathrm{O}$, most of their $F$, and part of their Si, the silicon doubtless being volatilized as silicon tetrafluoride. On this assumption the theoretical loss in welght on ignition of sample $2 a$ would be 21.1 percent; the actual loss was 21.0 percent. Thus the sillca content of the topaz is reduced by heating, and the product remaining, if essentially free of admixed quartz, is composed of alumina and silica in the ratio $3: 2.24$. Since this ratio in mullite is $3: 2$, calcination of the topaz should result in development of mullite with only a small quantity of excess silica. It is not clear from the analyses whether a small part of the iron and titanium are volatilized by heating, but the loss is not significant at the temperatures reached. As the gaseous $S 1 F_{4}$ may readily be 
Table 13.--Chemical analyses of topaz rock 1

\begin{tabular}{|c|c|c|c|c|c|c|c|}
\hline & \multicolumn{5}{|c|}{ Before heating } & \multicolumn{2}{|c|}{ After heating } \\
\hline & 1 & 2 & 3 & 4 & 5 & $2 a$ & $5 a$ \\
\hline 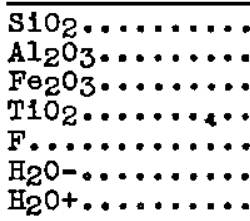 & $\begin{array}{r}33.00 \\
56.76 \\
\text { Trace } \\
2 / \\
13.23 \\
.04 \\
2.67\end{array}$ & $\begin{array}{r}33.12 \\
55.66 \\
.72 \\
.24 \\
13.94 \\
2.04 \\
2.06\end{array}$ & $\begin{array}{r}40.20 \\
51.79 \\
.21 \\
2 / \\
13.35 \\
\frac{2}{2}\end{array}$ & $\begin{array}{r}42.80 \\
48.62 \\
.98 \\
2 / \\
11.93 \\
2 / 2 / \\
1.51\end{array}$ & $\begin{array}{r}33.20 \\
50.10 \\
3.08 \\
2.96 \\
13.92 \\
2.36\end{array}$ & $\begin{array}{r}27.78 \\
71.62 \\
.86 \\
.32 \\
.20 \\
\ldots . . . \\
\ldots \ldots\end{array}$ & $\begin{array}{r}29.72 \\
63.78 \\
3.42 \\
3.32 \\
.11 \\
\ldots \ldots \\
\ldots . .\end{array}$ \\
\hline Minus $0=2 \mathrm{~F}$ & $\begin{array}{r}105.70 \\
5.57\end{array}$ & $\begin{array}{r}105.74 \\
5.87\end{array}$ & $\begin{array}{r}105.55 \\
5.63\end{array}$ & $\begin{array}{r}105.84 \\
5.03\end{array}$ & $\begin{array}{r}105.62 \\
5.86\end{array}$ & $\begin{array}{r}100.78 \\
.08\end{array}$ & $\begin{array}{r}100.35 \\
.05\end{array}$ \\
\hline $\begin{array}{l}\text { Loss in } \\
\text { welght. }\end{array}$ & 100.13 & $\begin{array}{l}99.87 \\
\ldots \ldots\end{array}$ & $\begin{array}{l}99.92 \\
\ldots \ldots\end{array}$ & $\begin{array}{c}100.81 \\
\ldots .\end{array}$ & 99.76 & $\begin{array}{c}100.70 \\
21.0\end{array}$ & 100.30 \\
\hline
\end{tabular}

1. Massive fine-gralned gray topaz rock. From Pardee, J. T., Glass, J. J., and Stevens, R. B., Massive low-fluorine topaz from the Brewer mine, South Carolina: Am. Mineralogist, vol. 22, p. $1061,1937$.

2. Massive coarse-grained topaz from westernmost topaz area. K. J. Murata, Geological Survey, analyst.

3. Fine-grained topaz mined from bedrock; representative sample of mill-lot ground through 300 mesh. Date supplied by Onited Feldspar \& Minerals Corporation.

4. Fine-gralned topaz float; representative sample of milllot ground through 300 mesh. Data supplied by United Feldspar \& Minerals Corporation.

5. Heavy concentrate from minus quarter-inch material from placer pit number 2 (see pl. 7); sink portion of bromoform (sp. g. 2.86) separation was crushed through 40-mesh screen and reseparated in methylene lodide (sp. g. 3.3); this sink portion was cleaned with an electromagnet and analyzed; sample contains a few percent kyanite and about 6 percent limenite. K. J. Murata, analyst.

2a. Same as number 2 but heated for half an hour at $1350^{\circ} \mathrm{C}$. K. J. Murata, analyst. Loss in welght determined by $R$. C. Wells, Geological Survey.

5a. Same as number 5 but heated for half an hour at $1350^{\circ} \mathrm{C}$. K. J. Murata, analyst.

1/ For additfonal analyses of the topaz rock, see Burgess, B. C., Topaz, a new industrial mineral: Ine. and Kin. Jour., vol. 142, pp. 57-58, sept. 1941.

2) Mot determined.

hydrolyzed by contact with water vapor, with precipitation of $\mathrm{SiO}_{2}$ and release of $\mathrm{HF}$, it seems possible that some compound of fluorine could be produced as a byproduct during calcination.

Origin and localization.--The topaz rock is clearly a product of replacement. Some of the rock replaced was partly or 
completely sillcified schist; some of it was unsilicifled schist, retaining the pattern of the fine-grained rhyolitic tuff and breccla from which it was derlved. The silicification of the schlst was probably accompanied by deposition of sulfides and gold. The topaz evidently was deposited later than, the silica, and apparently later than the sulfides and gold. The veins of "bull" quartz were formed after the deposition of the topaz.

The replacement bodies of topaz seem to be grouped along definite planes that cut both schist and silicifled rock, the fluids that carried the elements necessary for the formation of the topaz having apparently risen along branching fissures. The topaz-bearing solutions appear to have been directed by the major flssure system in the region, which is composed of two sets of steeply dipping fractures, one striking northeast and the other northwest. The irregular form of the bodies of topaz rock is evidently due to the uneven permeability of the wall rocks, for there seems to have been no selective replacement of certain minerals.

The transformation of the rhyolitic rocks to schist, the silicification, and the deposition of sulfides and gold may be related to the biotite granite that cuts the schist and is exposed a mile and a half northwest of the topaz area. The origin of the topaz and quartz veins is less clear.

Grade.--Estimates of the grade of the topaz bedrock deposits are made only for the body of rock in the easternmost area of topaz placer that is outlined in red on plate 7 . These est1mates are based largely on the amount of topaz recovered by the United Feldspar \& Minerals Corporation in exploratory open-pit mining operations up to August 1941. The map of the open pit (see pl. 9) shows that 1,106 tons of rock was removed, from which about 200 tons of topaz rock was hand-plcked. The topaz actually recovered amounted to 18.1 percent of all the material excavated. 


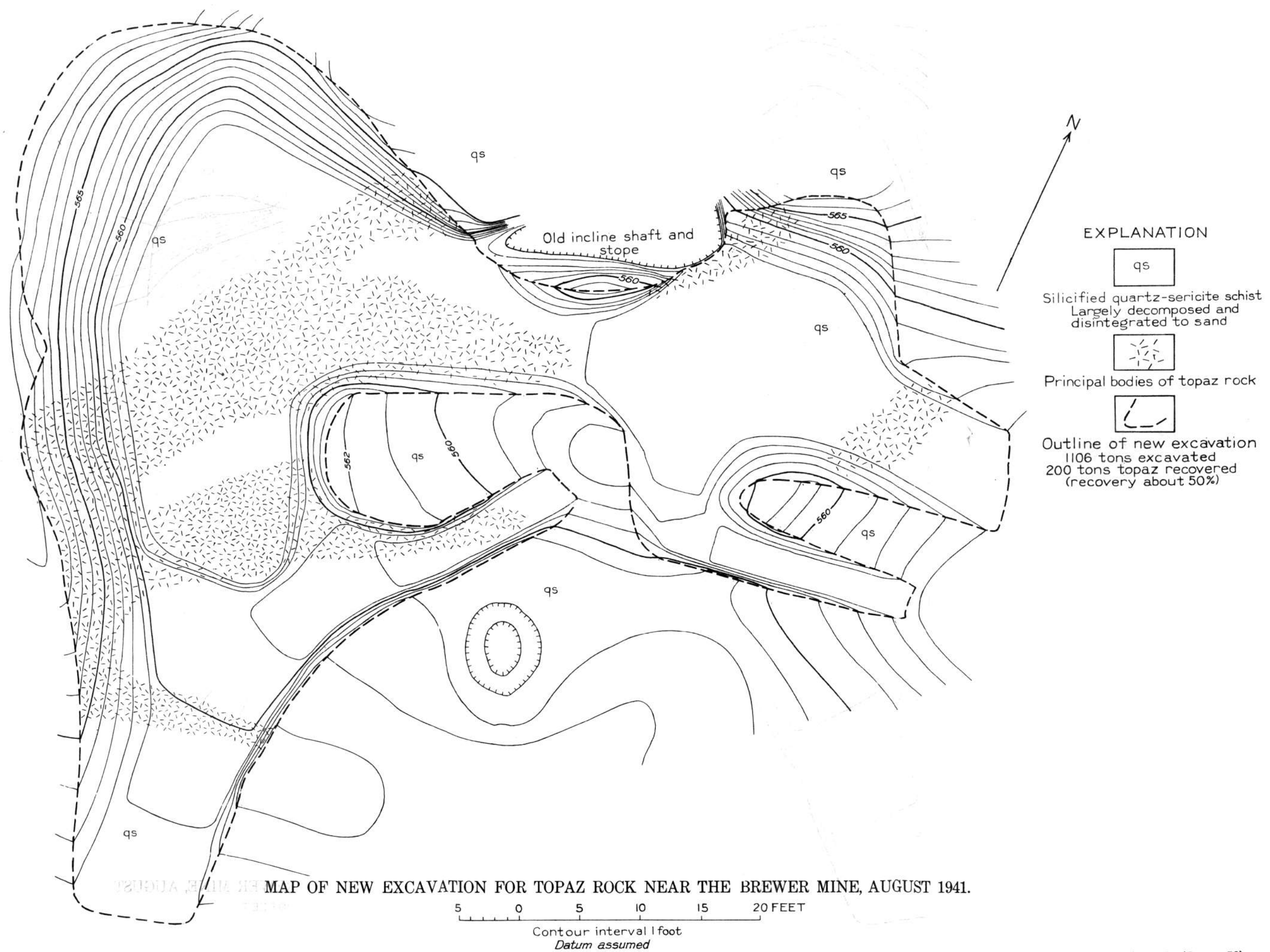


As no effort was made to recover rock containing more than a few percent of admixed quartz, or small pieces of topaz rock, a large part of the topaz in the deposit was thrown into the dumps; hand specimens of rock in which topaz was not visible to the naked eye proved to contain a few percent of topaz when crushed and separated in heavy liquid. Observations on the method of recovery and tests of the discarded material indicate that the dumps contain a quantity of topaz at least equal to that recovered, so that the material excavated contained about 35 percent topaz. The average grade, however, of all the rock in a roughly circular area encompassing the new excavation (see pl.9) is certainly much lower--probably between 15 and 20 percent--for considerable bodies of lower-grade rock were left unmined. The grada of the rock exposed in the old incline shaft and stope leading from the north side of the new open pit and in the long tunnel extending north from the bottom of the Brewer pit appears to be about the same. As the value of the topaz concentrates will probably be at least $\$ 15$ a ton at the mine and possibly as high as $\$ 30$, depending upon the size and purity of the material, ore containing 15 percent topaz would be worth from $\$ 2.25$ to $\$ 4.50$ a ton.

The grade of the topaz-bearing bedrock under placer areas 2 and 3 shown on plate 7 is not known, owing to lack of exploratory work, but there may be bodies there simllar to that under placer area 1.

The topaz in the area within the red lines on plate 7 occurs in a branch of the Brewer gold-bearing lode. Small pockets of gold ore are sald to have been removed from many of the old shallow workings in this area, and others may lie in the deeper unexplored rock. Assays of three samples of sillcifled rock, containing fine pyrite, collected by Pardee and Park $14 /$ from the

14 Pardee, J. T., and Park, C. P., Jr., op. c1t. 
walls of the Brewer pit show from 0.045 to 0.13 ounce of gold a ton. Recovery of gold in crude concentrates of these samples, crushed through a 20-mesh screen and panned to a ratio of about 70 to 1, was found by assays to be about 40 percent. Consequently, the silicified rock appears to contain about 0.04 ounce of recoverable gold a ton. Assuming that pockets of moderately high grade gold ore are scattered through the sillcified rock, and allowing for 15 percent topaz from which gold probably could not be recovered, it is reasonable to expect the body of rock outined in red to average at least 0.02 ounce of recoverable gold a ton, which might be recovered as a byproduct in milling the rock and concentrating the topaz.

Regerves.--Judging from the distribution of the topaz rock exposed in outcrops and in workings, the area of 25,000 square feet outlined by a solid red line on plate 7 seems to be of commercial grade (about 15 percent topaz). No massive topaz is exposed at the surface directly above the old drift extending north from the bottom of the Brewer pit. Exposures of topaz rock in the old incline shaft and stope along the north side of the new open pit (see pls. 7 and 9) indicate that the topaz is continuous to a depth of at least 50 feet. The block thus outlined contains about 106,000 tons of what is regarded as probable ore. Asguming an average topaz content of 15 percent, the block containg about 16,000 tons of topaz.

Exposures of topaz rock in the old drift extending north from the Brewer pit indicate that the ore body has an area of at least 10,000 square feet at that level, shown by the oval dotted red line on plate 7 . It seems reasonable to expect that the zone of topaz-bearing rock at the surface is continuous with that in the drift, and, as the drift is 130 feet below the bottom of the block of probable ore, the block of possible ore thus outlined contains about 194,800 tons. Assuming an average topaz 
content of 15 percent, this block contains about 29,000 tons of topaz.

The area of topaz ore at the level of the bottom of the Brewer pit may be much larger than has been indicated, as the old drift is not directly below the outcrops of topaz rock. There is no indication that the drift is near the bottom of the topaz deposit, but without further exploration it cannot be known to whet depth the topaz extends, although a total depth of at least 200 feet from the surface may be expected.

There may be ore of commercial grade under the two placer areas farther west, but no estimate of reserves can be made until some exploratory work has been done.

\section{Placer deposits}

Occurrence and distribution.--As topaz is highly resistant to weathering, pleces of topaz rock have been concentrated in the soil mantle over and around the areas underlain by topazbearing bedrock. This topaz float appears to have been moved downill from 1ts bedrock source largely by soll creep. The upper 1 to $2 \frac{1}{2}$ feet of the soll 1 s light yellow-brown and relatively free from clay. Below this the soil is bright red-brown and has a much higher clay content, being so sticiry that it can be washed from the pebbles only with much scrubbing. The percentage of topaz rock, except inmediately over a bedrock source, Is greater in the upper layer than in the lower. The pleces of topaz rock in the upper $3 \frac{1}{2}$ feet of the soll mantle are from a few millimeters to 6 inches in diameter, and about two-thirds of them are larger than a quarter of an inch. Heavy mineral concentrates made from the material that passes through a 20-mesh screen are composed largely of topaz and kyan1te, the latter forming from 5 to 60 percent. Ilmenite forms from 2 to 6 percent of the concentrates, and there are minor quantities of zircon, Iron oxides, cassiterite, matile, staurolite, and gold. 
The topaz-bearing placers form four separate areas, which are outlined by the outer broken green lines on plate 7. Placer area IA has been separated on the map from area 1 because the intervening ground elther is bedrock outcrop or has been so thoroughly dug up in the search for gold that it could not be adequately sampled. The topaz float extends beyond the limitg shown on the map, which enclose only the ground that contains more than 5 percent of coarse topaz (that in pieces larger than a quarter of an inch, the probable commerclal limit). However, most of the ground along the top of the ridge between placer areas 1, 2, and 3 is completely barren of topaz rock.

The topaz float that is scattered over the surface southwest of placer area $I A$ and south of area 2 appears to be residual from the eroded sediments of the coastal plain (see p. 63), and there may have been a concentration of topaz at the base of these sediments in some places. However, the scarcity of topaz In the base of the sedinents where exposed in the Hartman and Tanyard pits (see pl. 6) discouraged any extensive sampling during this investigation.

Grade.--In order to determine the grade of the placer, 23 pits were dug in the area mapped (pl, 7). The pits were dug from 2.0 to 4.5 feet deep, at which depths no more topaz could easily be seen in the material excavated. The walls of many old excavations showed thoroughly weathered bedrock at similar depths. A channel sample, about one square foot in average cross section, extending to the bottom of the pit and weighing from 300 to 800 pounds, was taken from each of the pits and thoroughly washed on quarter-inch screen. The oversize was spread out on a board platform, and the topaz rock was carefully plcked out by hand and weighed. The placer material in the pits was thus found to contain from 0.2 to 24.3 percent topaz (pl. 7). The results are recorded in table 14. 
Table 14.--Grade of topaz placer

\begin{tabular}{|c|c|c|c|c|c|c|}
\hline \multirow{2}{*}{$\begin{array}{l}\text { P1t } \\
\text { number }\end{array}$} & \multirow{2}{*}{$\begin{array}{l}\text { Depth } \\
\text { (feet) }\end{array}$} & \multicolumn{3}{|c|}{$\begin{array}{l}\text { Topaz in sample } \\
\text { (percent by wolght) }\end{array}$} & \multirow{2}{*}{\multicolumn{2}{|c|}{$\begin{array}{l}\text { Percent of } \\
\text { coarse topaz } \\
\text { relative to } \\
\text { total topaz } 2\end{array}$}} \\
\hline & & Coarse I] & Fine I/ & Total & & \\
\hline 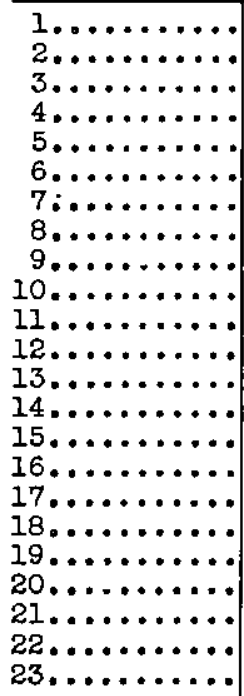 & $\begin{array}{l}4.0 \\
4.2 \\
3.7 \\
3.8 \\
2.2 \\
2.0 \\
3.7 \\
2.3 \\
2.7 \\
4.0 \\
3.7 \\
3.8 \\
4.5 \\
3.7 \\
2.5 \\
2.5 \\
3.5 \\
3.1 \\
3.0 \\
3.5 \\
3.2 \\
2.7 \\
3.7\end{array}$ & $\begin{array}{r}20.1 \\
15.1 \\
13.9 \\
9.7 \\
10.4 \\
1.7 \\
.5 .1 \\
3.0 \\
7.4 \\
3.3 \\
5.6 \\
4.7 \\
24.3 \\
2.3 \\
2.5 \\
.2 \\
2.5 \\
9.4 \\
7.8 \\
9.8 \\
4.6 \\
2.5 \\
17.7\end{array}$ & 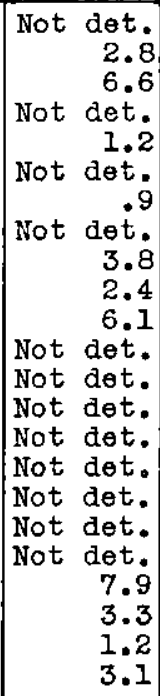 & \begin{tabular}{|rr} 
Not det. \\
17.9 \\
20.5 \\
Not det. \\
di.6 \\
Not det. \\
6.0 \\
Not det. \\
11.2 \\
5.7 \\
\\
11.7 \\
Not det. \\
Not det. \\
Not det. \\
Not det. \\
Not det. \\
Not det. \\
Not det. \\
Not det. \\
17.7 \\
7.9 \\
3.7 \\
20.8
\end{tabular} & & $\begin{array}{rr}\text { Not det. } & 84 \\
& 68 \\
\text { Not det. } & 90 \\
& 90 \\
\text { Not det. } & 85 \\
& \text { det. } \\
\text { Not de } & 66 \\
& 58 \\
& 48 \\
\text { Not det. } \\
\text { Not det. } \\
\text { Not det. } \\
\text { Not det. } \\
\text { Not det. } \\
\text { Not det. } \\
\text { Not det. } \\
\text { Not det. } \\
55 \\
58 \\
68 \\
85\end{array}$ \\
\hline
\end{tabular}

1/ "Coarse" topaz refers to topas in pleces larger than a quarter of an inch In diameter, "fine" topas to that in pleces smaller than a quarter of an Inch.

2/ The average proportion of coarse topaz to total topaz for areas 1 and IA 18 80 percent; for area 2, 57 percent; and for area 3, 67 percent (art thmettcal average).

Small channel samples averaging about 20 pounds each were taken from some of the pits in order to test the minus quarterinch material. These samples were screened dry on quarter-1nch screen; the two parts were welghed, and the undersize of each was panned by hand down to a ratio of about 3 to 1 . The concentrates were drled, and screened through a 20-mesh screen, and a representative portion of the undersize from each of seven samples was assayed for gold. Welghed portions of the oversize and the undersize were separated in bromoform (sp. g. 2.86), and the heavy fractions from the bromoform separations were then separated in methylene lodide (sp. 8. 3.3). On the basis of microscopic examination, it wes estimated that the heavy fractions of the methylene lodide separations were 95 percent topaz and the light fractions 50 percent topaz, that on the average about 
two-thirds of the total topaz is in sizes above a quarter of an inch. The kyanite in the concentrates was included in the welght of topaz, for its use is the same and its quantity small.

Judging from assays of some of the pan concentrates, placer areas 1 and $I A$ appear to contain about 50 cents worth of gold a cubic yard, but areas 2 and 3 contain less. All the gold seems to be free, the pyrite having been thoroughly oxidized, but as most of it is fine the most that could be recovered commercially is perhaps 20 cents worth a cublc yard.

Reserves.--The areas of placer are divided for the purpose of estimating reserves into blocks, outlined by the broken green lines on plate 7, that include ground of nearly uniform grade. The average depth of the ground, the average percent and the welght of coarse topaz in the varlous blocks are given by the green flgures on plate 7. The data are also tabulated in table 15, whlch gives an additional welght, for each area, of fine topaz (smaller than a quarter of an inch). The total welght of coarse topaz in the placers is about 8,750 tons; the weight of fine topaz is about 3,270 tons, but it is not certain whether all this is commercially recoverable.

\section{Recovery of topez and gold}

The body of topaz-bearing rock outlined in red on plate 7 would have to be mined by bulk methods, either from an open pit or from a glory hole feeding to the drift that extends north from the Brewer pit. Much of the topaz rock containg quartz, so that in order to recover all the topaz in the deposits much of the rock would have to be milled, the large pleces of pure topaz and some of the waste quartz rock being flist picked by hand from a moving belt. It probably would not be necessary to crush finer than 20 mesh. As topaz has a specific gravity of about 3.5 , It could be concentrated by a gravity method, such as 
Table 15.--Reserves of topaz in placer ground

\begin{tabular}{|c|c|c|c|c|c|}
\hline \multirow[b]{2}{*}{$\begin{array}{l}\text { Area and block } \\
(\text { see pl. } 7)\end{array}$} & \multirow[b]{2}{*}{$\begin{array}{c}\text { Average } \\
\text { depth } \\
\text { (ft.) }\end{array}$} & \multirow[b]{2}{*}{$\begin{array}{c}\text { Volume } \\
\text { (cu. yds.) }\end{array}$} & \multicolumn{2}{|c|}{ Coarse topaz } & \multirow{2}{*}{$\begin{array}{c}\text { Fine topaz } \\
\text { Tons }\end{array}$} \\
\hline & & & $\begin{array}{c}\text { Average } \\
\text { percent } \\
\text { by welght }\end{array}$ & Tons & \\
\hline 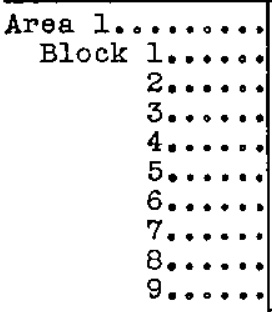 & $\begin{array}{l}3.0 \\
3.8 \\
2.5 \\
3.8 \\
2.5 \\
3.8 \\
2.5 \\
3.8 \\
2.5 \\
3.8\end{array}$ & $\begin{array}{r}\because 6,720 \\
780 \\
3,840 \\
830 \\
3,740 \\
870 \\
3,440 \\
60 \\
6,520 \\
\end{array}$ & $\begin{array}{r}3.0 \\
6.0 \\
8.0 \\
8.0 \\
10.0 \\
10.0 \\
12.0 \\
12.0 \\
14.0\end{array}$ & $\begin{array}{r}-350 \\
70 \\
460 \\
100 \\
560 \\
130 \\
620 \\
10 \\
1,370 \\
\end{array}$ & $\begin{array}{l} \\
\ldots \ldots \\
\ldots \ldots \\
\ldots \ldots \\
\ldots \ldots \\
\ldots \ldots \\
\ldots \ldots \\
\ldots \ldots \\
\ldots \ldots\end{array}$ \\
\hline Total..... & $\cdots$ & 26,200 & \begin{tabular}{|c|} 
Weighted \\
ave. 9.9
\end{tabular} & 3,870 & 970 \\
\hline 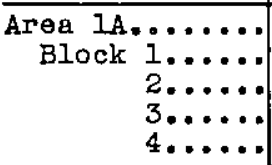 & $\begin{array}{l}\ddot{*} \cdot 0 \\
4.0 \\
4.0 \\
4.0\end{array}$ & $\begin{array}{r}\because, 240 \\
1,760 \\
2,970 \\
790\end{array}$ & $\begin{array}{r}\because \ddot{7} .5 \\
12.5 \\
17.5 \\
22.0\end{array}$ & $\begin{array}{r}\cdots \ddot{140} \\
330 \\
780 \\
260\end{array}$ & $\begin{array}{l}\quad 380 \\
\ldots \cdots \\
\cdots \cdots \\
\cdots \cdots \\
\cdots \cdots\end{array}$ \\
\hline Total...... & $\cdots$ & 6,760 & $\begin{array}{l}\text { We ighted } \\
\text { ave. } 14.9\end{array}$ & 1,510 & 380 \\
\hline Ares $2 \ldots . . . .$. & 3.0 & 11,220 & 6.0 & 1,010 & 760 \\
\hline 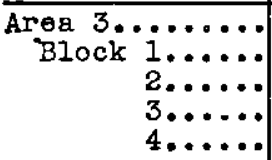 & $\begin{array}{l}\ddot{3} . \dot{2} \\
3.0 \\
3.2 \\
3.5\end{array}$ & $\begin{array}{r}\because 3,220 \\
1,110 \\
10,590 \\
3,340\end{array}$ & $\begin{array}{r}\because \cdots .0 \\
6.0 \\
6.0 \\
8.0 \\
14.0\end{array}$ & $\begin{array}{r}\cdots \\
290 \\
100 \\
1,270 \\
700\end{array}$ & $\begin{array}{l}1,160 \\
\ldots \ldots \\
\cdots \ldots \\
\cdots \ldots\end{array}$ \\
\hline & $\cdots$ & 18,260 & $\begin{array}{l}\text { Welghted } \\
\text { ave. } 8.6\end{array}$ & 2,360 & $i, 160$ \\
\hline Final totals... & $\ldots$ & 62,440 & $\begin{array}{l}\text { Weighted } \\
\text { ave. } 9.3\end{array}$ & 8,750 & 3,270 \\
\hline
\end{tabular}

Jigging or tabling, or by use of a slnk-and-float method employing heavy media. Although gravity methods would also concentrate all the other heavy minerals, only the iron oxides and pyrite would injure the product. An electromagnetic separation of the concentrates would eliminate the iron oxides, but not the pyrite. The pyrite probably will be largely oxldized to a depth of 170 feet, and much of that remaining can be eliminated by sorting out the waste quartz rock, in which most of the pyrite occurs. Some of the gold that is not free but in the pyrite would necessarily be lost, but most of the free gold could be recovered in the usual way by passing over mercury.

The lower part of the placer ground contains some sticky red clay, but so little that it probably will not cause appreciable 
loss of topaz; very thorough washing will be required, however, to clean the topaz. After washing, the topaz and the gold coul probably be recovered by the same method as that used for the material mined from bedrock. The coarse topaz would probably have to be crushed in order to obtain a nearly pure product. Although the percentage of ilmenite is rather high in the concentrates ( 2 to 6 percent) and cannot be removed with the electromagnet, this mineral, unlike iron oxide, appears to produce no discoloring effect on calcining. All the pyrite has been oxidized, but some of the gold thus freed would be lost in the slimes.

A supply of water can be obtained from Little Fork Creek, which rung half a mile southeast of the Brewer pit and carries a small surface flow the year round. 

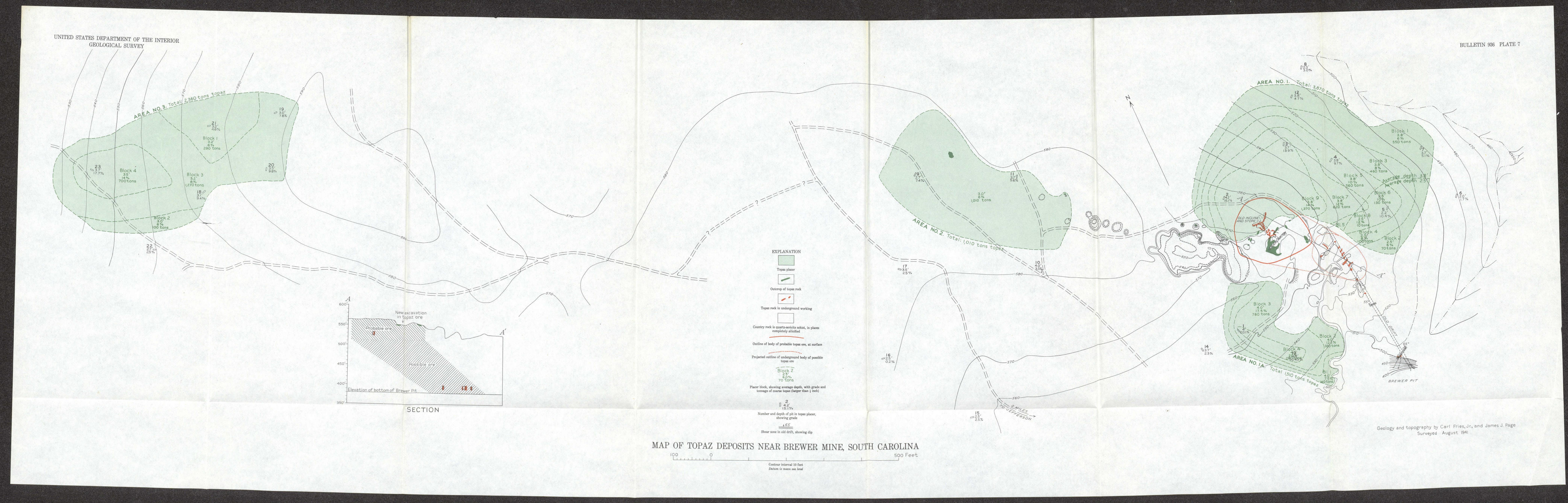
